\title{
51-Rusçada fiillerin görünüş kategorisine özgü semantik işaretler
}

\section{Özlem ÜNSAL ${ }^{1}$}

APA: Ünsal, Ö. (2020). Rusçada fiillerin görünüş kategorisine özgü semantik işaretler. RumeliDE Dil ve Edebiyat Araştırmaları Dergisi, (21), 823-835. DOI: 10.29000/rumelide.835795.

\section{Öz}

Dil bilgisinin en karmaşık kategorilerinden biri olarak gösterilen ve aspektolojinin inceleme alanına giren "görünüş kategorisi”, eylemin akışındaki bütünlük, süreç, uzunluk gibi farklılıkları yansıtan bir fiil kategorisidir. Rusçada категория вида (kategoriya vida) olarak adlandırılan ve "bitmişlikbitmemişlik" olmak üzere iki görünüş türüne dayanan kategori, Rusçadaki fiil işletiminin temelini oluşturması bakımından dil bilgisinin en önemli kategorileri arasında yer alır. Rusçada bitmiş ve bitmemiş görünüşlü fiiller, ön ek-son ek gibi oluşum biçimleri, ifade ettikleri zamansal paradigmalar, gerçekleşen eylemlere özgü bazı semantik işaretler, içerdikleri özel anlamlar gibi bir takım özellikler açısından birbirinden ayrılırlar. Görünüş türleri arasında semantik açıdan oluşan farklılıklar kategorinin işleyişini kavramada son derece önemli bir etken olarak karşımıza çıkar. Kategoriye özgü bu semantik farklılıklar, bazı ayırt edici anlamsal özellikler, eylemin meydana geliş biçimleri ve genel çerçevede belirlenen semantik işaretleri kapsar. Bunlar arasında semantik işaretler görünüş türlerinin sınırlarını belirlemede en belirgin özellik olarak değerlendirilir. Rusçada her bir semantik işaret yalnızca bir görünüş türüne ait olabileceği gibi bazı özel koşullar doğrultusunda her iki görünüş türünü de kapsayabilir. Bu çalışmada öncelikle Rusçadaki görünüş kategorisi genel bir çerçevede ele alınmış, daha sonra ise bitmiş ve bitmemiş görünüş türüne özgü semantik işaretler, görünüş ve zaman kategorisi üzerine önemli çalışmaları bulunan Rus Dilbilimci A. V. Bondarko'nun sınıflandırması temelinde ele alınarak incelenmiş ve her bir semantik işaret edebi örnekler çerçevesinde izah edilmiştir.

Anahtar kelimeler: Görünüş, semantik işaret, bitmiş görünüşlü fiil, bitmemiş görünüşlü fiil, Rusça

\section{Semantic signs of the category of aspect in Russian language}

\begin{abstract}
"The category of aspect", which is shown as one of the most complex categories of grammar and is included in the field of aspectology, is a verb category that reflects the differences such as integrity, process, duration in the flow of action. The category of aspect, which is called категория вида (kategoria vida) in Russian and is based on two types of appearances, "perfective-imperfective aspect", is among the most important categories of grammar in terms of forming the basis of verb category in Russian. In Russian language, perfective and imperfective verbs differ from each other in terms of their formation forms such as prefix-suffix, temporal systems they have, semantic features of actions and special meanings they contain. Semantic differences between types of verb aspects are very important factors in understanding the functioning of the category. These semantic differences belonging to the category include some specific semantic features, forms of action and
\end{abstract}

Arş. Gör., Atatürk Üniversitesi, Edebiyat Fakütesi, Rus Dili ve Edebiyatı Bölümü (Erzurum, Türkiye), o.dibekoglu@atauni.edu.tr, ORCID ID: 00oo-0001-7728-496X [Araştırma makalesi, Makale kayit tarihi: 02.10.2020kabul tarihi: 20.12.2020; DOI: 10.29000/rumelide.835795]

Adres 


\begin{abstract}
some semantic signs. Among these, semantic signs are considered as the most prominent feature in determining the boundaries of types of verb aspects. In Russian, each semantic sign may belong to only one type of verb aspect, or it may include both verb types according to some special conditions. In this study, the category of aspect in Russian language is dealt with in a general framework, the semantic signs of perfective and imperfective verbs are examined on the basis of the classification of Russian Linguist A. V. Bondarko, who carried out studies on the aspect and time category, and each semantic sign is examined within the framework of literary examples.
\end{abstract}

Keywords: Aspect, semantic sign, perfective verb, imperfective verb, Russian

\title{
Giriş
}

Dilbilimin alt disiplinlerinden biri olarak aspektolojinin alanına giren, bu bağlamda modern dilbilimde "aspekt" olarak da adlandırılabilen "görünüş" (Rusça вид), hem kavram hem de dil bilgisel bir kategori olarak dil bilgisinin en zor konularından biri olarak kabul edilir. Görünüşün kavramsal ve kategorik bir başlık olarak Rusçanın dil bilgisi içinde sahip olduğu özelliklere geçmeden önce fiil kategorisindeki yerini genel hatları ile izah etmek gerekir.

Karmaşık yapısı itibariyle "zaman", "kılınış" gibi fiile özgü diğer kavramlarla iç içe geçmiş olan "görünüş” kavramı, kılınış ve kiple ortak noktalara sahip olsa da ifade ettiği anlam ve özellikleri ile bu iki kavramdan ayrı bir kategori olarak değerlendirilir. Görünüşü kılınıştan ayıran özelliği genel bir ifade çerçevesinde belirtmek gerekirse, kılınış fiil kök ve gövdeleri ile ilgili iken görünüşte çekime uğramış olan fiilin taşıdığı kavramda, süreç bakımından konuşanın özel bir başkalaşma yapmış olması (Korkmaz, 2007: 576) durumu söz konusudur. Korkmaz (2007: 576) bu durumu, görünüşün nesnel değil öznel bir özellik taşıması ile açıklar ve söz konusu kavramı fiilin ad biçimi olan mastarda değil, çekimli şekillerinde görülen bir iç anlam olarak değerlendirir. Bu bağlamda görünüş kavramında anlamın önemli bir etken olduğu söylenebilir. Fiilin taşıdığı anlam açısından görünüş ve zaman arasında ortak bir durum, bir etkileşim söz konusudur. Görünüş ile zamanı birbirinden ayıran en önemli noktalardan biri ise, zamanın belirlenmesinde gönderim noktası olan konuşma anına bakılması durumu söz konusu iken, olayın doğasıyla, oluş biçimiyle ilgilenen görünüşte böylesine bir konumlamaya ihtiyaç duyulmamasıdır (Sebzecioğlu, 2016: 257). Bu bağlamda görünüşün öznel özelliği bir eylemin ortaya çıkış biçimini şekillendirebilir.

Türkçede söz konusu kavramların ayırt edilmesine yönelik yaklaşımın temelinde, görünüşün morfolojik açıdan zaman morfemleri ile ortaya çıması durumunun etken olduğu söylenebilir. Bu anlamda Türkçedeki "zaman" ve "görünüş" arasındaki ilişki Rusçadakinden daha farklı bir görüntü çizer. Türkçede bir fiilin bitmiş ya da bitmemiş özellikte olup olmadığ fiilin çekime uğraması, dolayısıyla eylemin ifade ettiği anlamla ilişkilendirilebilir. Rusçada ise fiilin mastar şeklinden ait olduğu görünüş türünü saptamak mümkündür. Burada her iki görünüş türünü yansıtan bazı oluşum biçimlerinin varlığı dikkat çeker. Bir alt başlıkta izah edilen bu oluşum biçimleri bitmiş ve bitmemiş görünüşlü bir fiili biçimsel açıdan tanımaya yardımcı olan bir faktör olarak değerlendirilebilir. Bununla birlikte "görünüş" kavramı ve bu kavramın ifade ettiği "semantik özellikler" arasındaki ilişki, kavramın anlaşılması, aynı zamanda bitmiş ve bitmemiş görünüşteki fiillerin doğru kullanımı açısından son derece önemli bir etken olarak karşımıza çıkar.

Rusçada görünüş kategorisine özgü anlamsal özellikler incelenirken kategori ile bağlantılı olarak eylemin başlangıç, sonuç, yoğunluk, kademeli bir şekilde ilerleme, devamlılık gibi biçimlerini izah

Adres

İstanbul Medeniyet Üniversitesi, Eğitim Bilimleri Fakültesi, Türkçe ve Sosyal Bilimler Eğitimi Bölümü, Türkçe Eğitimi ABD Cevizli Kampüsü, Kartal-İstanbul/TÜRKIYE e-posta: editor@rumelide.com 
eden "eylemin gerçekleşme biçimleri” (способы глагольного действия), somut-süreçsel, somutgerçek, devamlı-sürekli gibi görünüş türlerini yansıtan "özel/özgül” olarak adlandırılan anlam özellikleri (частновидовые значения) ve "süreçsellik", “uzunluk", "bütünlük” gibi görünüş türlerine özgü genel semantik işaretler (семантические признаки) ele alınır. Bu çalışmada Rusçada fiillerin görünüş kategorisini yansıtan "semantik işaretler" incelenmiştir. Semantik işaretlerin incelenmesi, söz konusu kategori üzerine önemli çalışmaları bulunan Rus dilbilimci A. V. Bondarko’nun sınıflandırması temel alınarak gerçekleştirilmiştir.

\section{Rusçadaki görünüş kategorisine genel bir bakış}

Rusça dil bilgisi çalışmaları içinde ayrı bir kategori olarak ele alınan görünüş kategorisi (категория вида), dil bilgisinin en karmaşık kategorilerinden biri olarak değerlendirilir. Birbirine zit iki tür ve bu türlerin özelliklerinden oluşan "görünüş kategorisi" en sade tanımıyla eylemin akışındaki farklılıkları ifade eden kategoriye verilen addır. Rusçada iki çeşit görünüş bulunur: bitmemiş görünüşlü fiiller (несовершенный вид-нсв) ve bitmiş görünüşlü fiiller (совершенный вид-св).

Rusçada görünüş biçimine göre fiiller, çift oluşturan (парные глаголы) ve çift oluşturmayan fiiller (непарные глаголы) olarak iki gruba ayrllır. Burada verilen bu iki kavramla hem bitmiş hem de bitmemiş görünüşe sahip iki adet fiilin varlığı kastedilmektedir. Buna göre çift oluşturan fiiller, sadece anlamsal olarak birbirinden ayrılan, leksik olarak özdeş bitmiş ve bitmemiş fiillerden oluşurken (делать-сделать, говорить-сказать), çift oluşturmayan fiiller ya tek görünüşe sahip (бежать, лететь) уа da anlamsal olarak her iki görünüş türünü de ifade eden (женить, казнить, исследовать) fiilleri kapsar (Polukhina ve Tumakova, 2014: 176).

Bitmiş görünüşlü fiiller, belirli bir sonuca ya da bitişine ulaşmış, tamamlanmış bir eylemi ifade ederken (прочитать), bitmemiş görünüşlü fiiller devam eden, tamamlanmamış ya da sonuca ulaşmamış eylemleri (чumamı) yansıtırlar (Kasatkin, Klobukov ve Lekant, 2004: 152). Bu fiiller, ön ek-son ek gibi oluşum biçimleri, sahip oldukları zamansal paradigmalar, ifade ettikleri eyleme yönelik semantik işaretler, özel ve genel kullanım durumları gibi bir takım biçimsel, dil bilgisel ve anlamsal özellikler açısından birbirinden ayrllırlar. Her iki görünüş türüne ait düzenli bir dil bilgisel gösterenden pek söz edilemese de fiillerin hangi türe ait olduğunu belirlemede bazı temel gösterenlerden yararlanılabilir. Şelyakin (1983: 112) bu gösterenleri kelime yapıcı ön ekler (словообразовательные приставки), kelime yapıcı son ekler (словообразовательные суффиксы), fiil kökündeki değişiklik (чередование в корне), vurgu yerinde değişiklik (перемещение ударения) ve supletivizm yani fiilin tamamen değişimi (супплетивизм) şeklinde sınıflandırır. Bu sınıflandırmaya göre bir fiilin görünüş türünü saptamak için biçimsel yapısını incelemenin gerekli olduğu söylenebilir:

Дарить - ㅁoдарить (hediye etmek): kelime уарıсı ön ek -по; опаздцъвать - опоздать (geç kalmak): kelime уарıсı son ek -ыва-; понимать - понять (anlamak): fiil kökünde değişiklik; рассып `ать - расс `ыпать (serpmek, dökmek): vurgu yerinde değişiklik; говорить - сказать (söylemek, konuşmak): fiilin tamamen değişimi.

Fiillerin oluşum biçimi ve hangi görünüş türüne ait olduğunu saptamak için sinıflandırılan bu gösterenler, fiilin morfolojik yapısı hakkında da bilgi verir. Ön ek (приставка), son ek (суффикс), kelime köküne getirilen ek (аффикс), kök (корень), gövde (основа) gibi kavramlarla tanıştıran bu morfolojik yapı bir fiilin biçimsel yapısını incelemeye de imkan verir. Rusçada bitmiş ve bitmemiş

\footnotetext{
Adres $\mid$ Address

İstanbul Medeniyet Üniversitesi, Eğitim Bilimleri Fakültesi, Türkçe İstanbul Medeniyet University, Faculty of Education Sciences, ve Sosyal Bilimler Eğitimi Bölümü, Türkçe Eğitimi ABD Cevizli Turkish and Social Scinces Education, Turkish Language Teaching Kampüsü, Kartal-İstanbul/TÜRKIYE $\quad$ Education, Cevizli Campus, Kartal-İstanbul /TURKEY e-posta: editor@rumelide.com 1 e-mail: editor@rumelide.com
} 
görünüşlü fiillerin biçimsel farklılıkları dışında dil bilgisel farklılıkları da bir fiilin ait olduğu türü ve bu türün ifade ettiği anlamı belirlemede etkili bir durumdur. Bunun yanı sıra bu dil bilgisel farklılıklar, fiilin doğru bir dil bilgisi biçiminde kullanımı için son derece önemli bir faktör olarak karşımıza çıkar.

Bitmiş görünüşlü fiiller bildirme kipinde sadece geçmiş ve gelecek zamanı ifade ederken, bitmemiş görünüşlü fiiller geçmiş ve gelecek zamanın yanı sıra şimdiki zaman biçimine de sahiptir, gelecek zamanın bitmemiş görünüşlü fiillerdeki ifadesi analitik özelliklidir (Beloşapkova, 1989: 467):

Bildirme kipindeki bitmiş görünüşlü fiiller: сделал (уaptım/yaptın/yaptı), сделала (yaptım/yaptın/yaptı), сделало (уарtı), сделали (yaptık/yaptını//yaptılar) - geçmiş zaman; сделаю (уарасаğım), сделаешь (yapacaksın), сделает (yapacak), сделаем (уарасайız), сделаете (yapacaksını), сделают (yapacaklar) - gelecek zaman.

Bildirme kipindeki bitmemiş görünüşlü filller: делаю (уаріуоrum), делаешь (уарıуorsun), делает (уарıуоr), делаем (уаріуоruz), делаете (yapıyorsunuz), делают (yapıyorlar) - şimdiki zaman; делал (yaptım/yapıyordum, yaptın/yapıyordun, yaptı/yapıyordu), делала, (yaptım/yapıyordum, yaptın/yapıyordun, yaptı/yapıyordu), делало (yaptı/yapıyordu), делали (yaptık/yapıyorduk, yaptınız/yapıyordunuz, yaptılar/yapıyordular) - geçmiş zaman; буду делать (уарасаğım), будешь делать (yapacaksın), будет делать (yapacak), будем делать (уарасайız), будете делать (yapacaksını), будут делать (yapacaklar) - gelecek zaman.

En basit haliyle yukarıdaki gibi formüle edebileceğimiz görünüş türünün ifade ettiği zaman biçimleri bağlam sınırları içinde daha karmaşık bir yapıya sahiptir. Her iki görünüş türü kullanım açısından bir seçenek oluşturmaz, yani birbirleri yerine kullanılamazlar. Daha açık ifade etmek gerekirse, bitmiş ve bitmemiş görünüşlü fiillerin kendi içlerinde sahip olduğu bir takım kurallar söz konusudur. Bu kurallar görünüş türlerinin ifade ettikleri anlamsal sınırlar çerçevesinde ortaya çıkar. Rusçada bu sınırları belirleyen en temel etken ise görünüş türlerine özgü bazı semantik işaretlerin varlığıdır.

\section{Görünüsş kategorisine ait semantik işaretler}

Rusçada morfolojinin inceleme alanına giren görünüş kategorisi oluşum şekilleri, görünüş türleri, zamansal paradigmalar gibi fiile özgü biçimsel, dil bilgisel ve semantik birtakım özellikleri yansıtır. Ancak Rusçada "görünüş” kavramı, eylemin meydana gelişindeki süreç, güncellik, sonuç gibi olgularla, dolayısıyla da eylemin kendisi ile sıkı bir ilişki içindedir. Bu açıdan kategorinin anlam bakımından ifade ettiği farklılıkların daha çok ön planda olduğu görülür. Görünüş türlerini yansıtan semantik özelliklerin iyi bir şekilde kavranması, türlere ait fiillerin doğru kullanımını da destekler.

Rusçada görünüş kategorisinin semantik yönü ile ilgili temel sayllabilecek birkaç kavramdan bahsedilebilir. Bu kavramlar her iki görünüş türüne ait semantik işaretler, genel ve ayırt edici özellikler, eylemin temel biçimleri şeklinde alt başlıklarla sınıflandırılır. Rusçada görünüş kategorisi ile ilgili gerçekleştirilen teorik içerikli çalışmalara bakıldığında bu kavramlara sıklıkla yer verildiği görülür.

İşlevsel dil bilgisi, Rusça fiillerin semantiği, görünüş ve zamanda anlam, morfolojik kategorilerin genel teorisi gibi dil bilgisi ve anlam bilimi üzerine çalışmaları bulunan A. V. Bondarko, Rusça Füillerde Görünüş ve Zaman (Вид и время русского глагола-1971) adlı çalışmasında Rusçadaki görünüş ve zaman kategorilerinin semantik içeriği ve işleyişini incelemiş, "görünüş" kategorisinin semantik potansiyelleri çerçevesinde temel işaretleri sınıflandırarak bitmemiş ve bitmiş görünüşlü fiillere ait

\footnotetext{
Adres $\mid$ Address

İstanbul Medeniyet Üniversitesi, Eğitim Bilimleri Fakültesi, Türkçe İstanbul Medeniyet University, Faculty of Education Sciences, ve Sosyal Bilimler Eğitimi Bölümü, Türkce Eğitimi ABD Cevizli Turkish and Social Scinces Education, Turkish Language Teaching Kampüsü, Kartal-İstanbul/TÜRKIYE $\quad$ Education, Cevizli Campus, Kartal-İstanbul /TURKEY e-posta: editor@rumelide.com 1 e-mail: editor@rumelide.com
} 
özel durumları ortaya koymuştur. Bitmemiş ve bitmiş görünüşlü fiillere özgü semantik işaretler eylemin sınırları ile ilgili genel işaretleri ifade ederken iki görünüşün ifade ettiği özel anlamlar ise semantik işaretlerin detaylandırılmış biçimleri olarak karşımıza çıkar.

A. V. Bondarko (1971: 11), görünüş türlerinin semantik içeriğini onların işlevsel kapasitelerinin toplamı, semantik potansiyelleri olarak tanımlar ve semantik işaretleri her iki gruba göre sinıflandırır. $\mathrm{Bu}$ semantik işaretler bütünlük (целостность), süreçsellik (процессность), sinırlandırılmışlık / sinırlandırılmamışlı (локализованность / нелокализованность), uzunluk (длительность), ani meydana geliş (внезапное наступление действия), eş zamanlllı (одновременность) ve ardışıklıktan (последовательность) oluşur. Eylemin gerçekleşme biçimindeki anlamsal olguları ifade eden her bir semantik işaretin ait olduğu bir görünüş türü (bitmiş ya da bitmemiş) mevcuttur.

Bondarko'nun sınıflandırmasından yola çıkarak sıralanan işaretlerden bütünlük (целостность), sıralı oluş/ardışıklık (последовательность), ani meydana geliş (внезапное наступление факта) çoğunlukla bitmiş görünüşlü fiillere özgü semantik işaretler iken, süreçsellik (процессность), еş zamanlılık (одновременность), sinırlandırılmışlık / sinırlandırılmamışlık (локализованность / нелокализованность) ve uzunluk (длительность) bitmemiş görünüşlü fiilleri ifade eden işaretlerdir. Ancak bu işaretlerden bazılarının söz dizimsel ve leksik gibi bir takım özelliklere dayalı olarak sınırlı ya da olası kullanım dahilinde her iki kategori türünü yansıttığı durumlar da söz konusu olabilir. Bu bağlamda belirgin gösterenlere sahip bir semantik işaret çoğunlukla tek bir görünüş türünü yansıtsa da bazı özel koşullar çerçevesinde ait olmadığı görünüş türünü de ifade edebilir. Bu özel koşullar söz dizimsel bir birim olan cümlenin yapısı açısından önem arz eder. Nitekim söz dizimsel birimlerin diziminde konuşan kişinin leksik seçimi, aktardiğı düşüncenin gerçekliği üzerine nasıl bir yön vermek istediği ile ilgilidir (Bak, 2017: 38). Bu seçim anlatıma farklılık kazandırarak ifade edilmek istenen düşünceyi güçlendirir.

Belirtilen özel koşullar ve semantik işaretlere ait özelliklerin daha net bir şekilde anlaşılabilmesi için aşağıda bu kavramları tek tek ele almaya çalışalım.

\section{Bütünlük}

Rusçada dil bilgisel açıdan bakıldığında daha çok eylemin bitmiş biçimiyle (совершенный вид) ilişkilendirilen целостность (bütünlük) semantik işaretinin kelime anlamı sözlükte bölünmezlik, birlik-“нераздельность, единство” (Ojegov ve Şvedova, 2008: 873) şeklinde verilir. Bu bağlamda bütünlük kavramı için eylemin belirlenen sınıra kadar devam etme, dolayısıyla bölünmezlik özelliğini ifade ettiği söylenebilir.

Bondarko'nun "görünüş” konulu çalışmalarında sıkça atıfta bulunduğu dilbilimci Yu. S. Maslov'un çalışmasında Rusçadaki görünüş kategorisinin bitmiş ve bitmemiş görünüşlü fiillerden oluştuğunu ifade ettiği cümlesinde aynı zamanda söz konusu semantik işareti de yorumladığı görülür (2006: 177): "Rusça ve diğer Slav dillerinde genellikle kendi sintrlarma ulaşan, bölünemez bütün bir eylemi ifade eden bitmiş görünüşlü ve bir bütünlüğe işaret etmeyen, özellikle bitiş sıntrna yönlendirilen ancak bu sinıra ulaşmayan, akış veya tekrarlanma sürecindeki eylemi ifade eden bitmemiş görünüşlü fiil kıyaslanır." O halde görünüş kategorisinin en belirgin işaretlerinden biri olarak kabul edebileceğimiz "bütünlük" işareti bitmiş görünüşlü fiilleri yansıtan semantik bir işarettir, bitmemiş görünüşlü fiiller ise genel olarak bütünlüğü olmayan fiilleri ifade eder. Ancak A. V. Bondarko (1971: 13) bazı durumlarda, özellikle söz dizimsel ve leksik koşulların oluşması durumunda bitmemiş görünüşlü

\footnotetext{
Adres $\mid$ Address

İstanbul Medeniyet Üniversitesi, Eğitim Bilimleri Fakültesi, Türkçe İstanbul Medeniyet University, Faculty of Education Sciences, ve Sosyal Bilimler Eğitimi Bölümü, Türkçe Eğitimi ABD Cevizli Turkish and Social Scinces Education, Turkish Language Teaching Kampüsü, Kartal-İstanbul/TÜRKIYE $\quad$ Education, Cevizli Campus, Kartal-İstanbul /TURKEY e-posta: editor@rumelide.com 1 e-mail: editor@rumelide.com
} 
fiillerin anlatımın bağlamına göre bütünlüğü yansıtabileceğini de belirtir. Bondarko’nun belirttiği durumun özellikle edebi özellik taşıyan anlatımlarda yer aldığı söylenebilir.

\section{Örnekler}

- Она кончила снимать перчатки и развернула газету, которую только что привезли c nочты. (A. Çehov, Asma Katlı Ev): Bitmiş görünüşlü fiil (CB) - bütünlük

(Eldivenlerini çıkarma işini bitirdi ve postaneden yeni gelen gazeteyi açtı.)

- Потом мы спустились вдоль берега к югу. (İ. Bunin, Kafkas): Bitmiş görünüşlü fiil (CB) bütünlük

(Sonra biz sahil boyunca güneye indik.)

- В мутном воздухе раздался сухой, краткий щелчок. (M. Gorki, Bozkrrda): Bitmiş görünüşlü fiil (CB) - bütünlük

(Sisli havada cansız, kısa bir ses yayıldr.)

- Вероятно, лицо мое ужасно, голос странен, потому что жена вдруг бледнеет и громко вскрикивает каким-то тоже не своим, отчаянным голосом. (A. Çehov, Slkıсı Bir Öykü): Bitmemiş görünüşlü fiil (HCB) - hikaye şimdiki zaman anlatımı - bütünlük

(Muhtemelen yüzüm berbat, sesim de bir tuhaf, nitekim karmm benzi birden soluyor, kendinin olmayan, çaresiz bir ses tonuyla çı̆glık atıyor.)

\section{Süreçsellik}

Yukarıda bitmiş görünüşlü fiillere özgü olduğu belirtilen "eylemin bütünlüğü” semantik işaretine aksi bir özelliği niteleyen "süreçsellik" işareti, eylemin belli bir süreç içerisinde gerçekleştiğini gösterir.

Süreçsellik eylemin "bitmemişlik" görünüşü ile doğrudan bağlantılı bir işaret olarak karşımıza çıkar. Nitekim bitmemiş görünüşlü fiiller, eylemin sinıra ulaştığın işaret eden bir göstereni içermezler, eylemin gerçekleşmesi bir gelişim aşamasına, sürece bağh bir durumdur (Rozental, Golub ve Telenkova, 2010: 227): Они читают газету (onlar gazete okuyorlar), они будут читать газету (onlar gazete okuyacaklar), они читали газету (onlar gazete okuyorlardı). Birinci cümle "gazete okuma” eyleminin şimdiki zamanda gerçekleştiğini, ikinci cümle gelecek zamanda gerçekleşeceğini, üçüncü cümle ise geçmişte gerçekleştiğini gösterir, üçüncüsü geçmiş zamanda gerçekleşse de eylemin sınıra ulaşıp ulaşmadığına işaret eden bir gösterenin varlığına rastlanmadığı görülür. Söz konusu semantik işaret bitmiş görünüşlü filleri hiçbir zaman ifade etmezken, her zaman olmasa da bitmemiş görünüşlü fiillere özgü bir işaret olarak değerlendirilir.

\section{Örnekler}

- Дядя Яков всё более цепенел; казалось, он крепко спит, сцепив зубы, только руки его живут отдельной жизнью. (M. Gorki, Çоcukluk): Bitmemiş görünüşlü fiil (HCB) süreçsellik - temel gösteren: всё болеe (gittikçe daha çok).

(Yakov Amca gittikçe daha da uyuşuyordu; uykusu derin gibiydi, dişlerini birbirine kenetlemiş, bir tek elleri ayru telden çalıyordu.)

- Чем они удивительны, она не совсем понимала, но чувствовала постоянно. (İ. Bunin,

\footnotetext{
Adres $\mid$ Address

İstanbul Medeniyet Üniversitesi, Eğitim Bilimleri Fakültesi, Türkçe İstanbul Medeniyet University, Faculty of Education Sciences, ve Sosyal Bilimler Eğitimi Bölümü, Türkce Eğitimi ABD Cevizli Turkish and Social Scinces Education, Turkish Language Teaching Kampüsü, Kartal-İstanbul/TÜRKIYE $\quad$ Education, Cevizli Campus, Kartal-İstanbul /TURKEY e-posta: editor@rumelide.com 1 e-mail: editor@rumelide.com
} 
Kuru Vadi): Bitmemiş görünüşlü fiil (HCB) - temel gösteren: постоянно (sürekli) (Hayrete değer neyi var tam anlamıla anlayamıyor ama bunu sürekli hissediyordu.)

- А казаки все еще говорили промеж собой, и всю ночь стояла у огней, приглядываясь пристально во все концы, трезвая, не смыкавшая очей стража. (N. Gogol, Taras Bulba): Bitmemiş görünüşlü fiil (HCB) - temel gösteren: все еще (hala)

(Kazaklar ise hala aralarında konuşuyorlard, tüm gece ateşin başında gözlerini hiç kapatmayan, ayık bir şekilde, tüm yönleri dikkatle kontrol eden muhafizlar duruyordu.)

\section{Sınırlandırılmışlık/sınırlandırılmamışlık}

Dil bilimsel bir kavram olarak düşünüldüğünde "zamansal sınırlandırılmışlık” olarak da adlandırllan "sınırlandırılmışlık" semantik işareti sıklıkla işlevsel dil bilgisi alanı içinde incelenen bir kavram olarak karşımıza çıkar. Anlam bilimsel bir kategori olarak nitelendirilen işaret "sınırlı" ve "sınırlı olmayan" olmak üzere iki kavram üzerinden değerlendirilir.

"Sınırlandırılmışlık" tek yönlü ve geri dönülemez bir zaman akışında gerçekleşen belirli süreç ve olayların somut konumlarını yansıtırken, "sınırlandırılmamışlık" süreç ve olayların düzenli ya da düzenli olmayan sürdürülebilirliğini ifade eder (Bondarko, 1987: 211). Bu bağlamda birbirinden bağımsız olarak düşünülemeyen bu iki kavramdan ilkinin somut, ikincisinin ise somut olmayan bir süreci yansıttığı söylenebilir. Daha açıklayıcı bir şekilde ifade etmek gerekirse söz konusu kavramlar Rusçadaki sıklık ve belirli bir zaman dilimini ifade eden zarfların kullanımı ile ortaya çıkar. Bunlar, редко (nadiren), часто (sık sık), обычно (genellikle), иногда (bazen), по временам (zaman zaman), сейчас (şimdi), ранъше (önceden) gibi zarflardır. Сейчас ile ifade edilen bir eylem "şu anı" kapsadığı için "sınırlandırılmışlık" söz konusu iken "иногда" ile belirtilen bir eylemin somut olmayan bir süreci yansıttığı için "sınırlandırılmamışlı̆̆ı" ifade ettiği söylenebilir.

Yukarıda verilen ve söz konusu iki kavramı da yansıtan zarfların kullanımı Rusçada bitmemiş görünüşlü fiillere özgü olduğu için semantik işaretin çoğunlukla bitmemiş filleri yansıttı̆̆ söylenebilir.

\section{Örnekler}

- О своем прошлом эти люди мало говорили друг с другом, вспоминали о нем крайне редко, всегда в общих чертах и в более или менее насмешливом тоне. (M. Gorki, Bir Zamanlar İnsan Olanlar): Bitmemiş görünüşlü fiil (HCB) - sınırlandırılmamışlık - temel gösteren: крайне редко (çok nadiren)

(Bu insanlar birbirleriyle geçmişleri hakkında çok az konuşuyor, çok az hatırlyyor, eski günleri her zaman yüzeysel olarak, alaycı bir tonda geçiştiriyorlardı.)

- $\quad$ Иногда я уходил из дому и до позднего вечера бродил где-нибудъ. (A. Çehov, Asma Kath $E v$ ): Bitmemiş görünüşlü fiil (HCB) - sınırlandırılmamışlık - temel gösteren: иногда (bazen).

(Bazen evden çıkıyordum ve geç saatlere kadar bir yerlerde dolaşıyordum.)

- $\quad$ Я в город, на ярмонку еду сейчас - что тебе купить? (İ. Bunin, Yolda): Bitmemiş görünüşlü fiil (HCB) - sınırlandırılmışlık - temel gösteren: сейчас (şimdi).

(Şimdi şehre, fuara gidiyorum, sana ne alayım?)

\footnotetext{
Adres $\mid$ Address

İstanbul Medeniyet Üniversitesi, Eğitim Bilimleri Fakültesi, Türkçe İstanbul Medeniyet University, Faculty of Education Sciences, ve Sosyal Bilimler Eğitimi Bölümü, Türkce Eğitimi ABD Cevizli Turkish and Social Scinces Education, Turkish Language Teaching Kampüsü, Kartal-İstanbul/TÜRKIYE $\quad$ Education, Cevizli Campus, Kartal-İstanbul /TURKEY e-posta: editor@rumelide.com 1 e-mail: editor@rumelide.com
} 


\section{Uzunluk}

Rusçada görünüş kategorisinin zamanla bağıntılı semantik bir işareti olarak karşımıza çıkan uzunluk (длительность) işaretinin sözlükteki kelime anlamı, zamanda süre/uzunluk“продолжительность, протяжение во времени” (Lopatin ve Lopatina, 2001: 129) şeklindedir.

Eylemin belirli bir zaman içindeki uzunluğunu/süresini ifade eden söz konusu semantik işaret, "süreçsellik" gibi doğrudan bitmemiş görünüşlü fillerle bağlantılı bir özellik olarak karşımıza çıkar. Uzunluk anlamsal içerikte долго (иzun süre), целый день (tüm gün), пока (...nспауa kadar) gibi kelimelerle vurgulanabilir (Gureviç, 2008: 93). Bitmemiş görünüşlü bir fiille kullanılan bu tür kelimeler eylemin belirtildiği zaman içindeki uzunluğuna işaret eder. Bu bağlamda semantik bir işaret olan "uzunluk" işaretinin her zaman olmasa da çoğunlukla bitmemiş görünüşlü fiilleri ifade ettiği söylenebilir.

Bondarko (1971: 14), bitmiş görünüşlü fiillerin долго (uzun süre), два часа (iki saat), три года (üç yll) gibi zarflarla olan sınırlı uyumuna dikkat çekerek bu zarfların uzunluk özelliği taşıması sebebi ile uzunluk semantik işaretinin söz dizimsel ve leksik bir takım koşullara bağlı olarak bitmiş görünüşlü fiilleri de yansitabileceğini belirtir. Dilbilimcinin ifade ettiği durum, belirtilen zarfların fiillerle kullanımı dikkate alındığında tüm bitmiş fiiller için geçerli değildir. Burada eylemin uzunluğuna işaret edecek biçimsel bir gösterene ihtiyaç vardır. Bu biçimsel gösterenler eylemi belirli bir zaman içinde sınırlandıran no-, nро- ön ekleridir. Пo- ön ekli bazı fiiller, eylemin gerçekleştiği zamana istinaden "sınırlı" bir zaman dilimini yansitırlar. Bu fiiller eyleme bağlamsal içerik olarak "biraz, bir süre yapmak” anlamını katar. Söz konusu fiil grubuna почuтать (okumak), побегать (koşmak), погулять (gezmek), посидеть (oturmak) gibi fiiller örnek olarak gösterilebilir. Про- ön ekli bazı fiiller ise belirli bir süre içinde gerçekleşen eylemi ifade ederler, bu eylemlerin verilen süreyi tümüyle "doldurduğu" düşünülebilir (Zaliznyak ve Şmelev, 2000: 112). Bu fiiller de eyleme "bir süre yapmak" anlamı katar. Belirtilen gruba прожить (yaşamak, geçirmek), пробыть (bulunmak), проработать (çalışmak) gibi fiiller örnek olarak gösterilebilir.

\section{Örnekler}

- Проводив прохожих, она долго оглядывала пустую избу: нельзя ли продать что? (і். Bunin, Neşeli Ev): Bitmemiş görünüşlü fiil (HCB) - uzunluk - temel gösteren: долго (uzun süre)

(Yoldan geçenleri uğurladıktan sonra uzunca bir süre boş izbeyi süzdü: bir şey satılamaz mıydı?)

- Ц Целый день она не разговаривала со мною, а вечером, прежде чем встать на молитву, присела на постель и внушительно сказала памятные слова. (M. Gorki, Çосиkluk): Bitmemiş görünüşlü fiil (HCB) - uzunluk - temel gösteren: целый день (tüm gün)

(Tüm gün benimle konuşmad, akşam ise duaya kalkmadan önce yatağa oturdu ve etkileyici bir şekilde unutulmaz sözler sarf etti.)

- Он три дня пробыл на своем участке и теперь приехал в Дубечню на паровозе, а к нам со станции пришел пешком. (A. Çehov, Benim Hayatım): Bitmiş görünüşlü fiil (CB) uzunluk - temel gösterenler: три дня (üç gün), про- ön eki

( $O$, kendi bölgesinde üç gün geçirdi ve buharl lokomotifle Dubeçnya'ya geçti, bize ise istasyondan yürüyerek geldi.)

\footnotetext{
Adres $\mid$ Address

İstanbul Medeniyet Üniversitesi, Eğitim Bilimleri Fakültesi, Türkçe İstanbul Medeniyet University, Faculty of Education Sciences, ve Sosyal Bilimler Eğitimi Bölümü, Türkce Eğitimi ABD Cevizli Turkish and Social Scinces Education, Turkish Language Teaching Kampüsü, Kartal-İstanbul/TÜRKIYE $\quad$ Education, Cevizli Campus, Kartal-İstanbul /TURKEY e-posta: editor@rumelide.com 1 e-mail: editor@rumelide.com
} 
- Вскоре мне стало известно, что человек этот недавно вернулся из ссылки, из Якутской области, где он прожил десять лет. (M. Gorki, Benim Üniversitelerim): Bitmiş görünüşlü fiil (CB) - uzunluk - temel gösterenler: десять лет (on yll), про- ön eki

(Çok geçmeden bu adamın geçenlerde, on yılını geçirdiği Yakutsk Bölgesinden, sürgünden döndüğünü öğrendim.)

\section{Ani meydana geliş}

Bondarko'nun görünüş kategorisine özgü semantik işaretler sınıflandırmasında yer verdiği ve eylemin "aniden meydana gelme” özelliği ile bitmiş görünüşlü fiilleri doğrudan yansıtan bir diğer işaret "eylemin aniden vuku buluş ifadesi” (выражение внезапного наступления факта) olarak karşımıza çıkar.

"Eylemin aniden gerçekleşmesi" olarak adlandırılan bu semantik işaret, konu ile ilgili çalışmaların bir çoğunda eyleme "anilik" (мгновенность) özelliği kazandıran kelimelerin kullanımı ile açıklanır. Nitekim bazı durumlarda fiillerin söz dizimsel uyumlarının "görünüş" kategorisine bağlı olduğunu ifade eden Şelyakin (1983: 8), söz konusu bağlllık doğrultusunda "anilik" (мгновенность), "birdenbirelik" (неожиданность), "tamlık" (полнота) anlamlarını taşıуаn вдруг (birden), внезапно (aniden), совсем (büsbütün, hepten) gibi kelimelerin bitmiş görünüşlü fiillerle uyum sağladığını belirtir. Bu bağlamda söz konusu semantik işaretin çoğunlukla bitmiş görünüşlü fiillere özgü bir işaret olduğu söylenebilir. Ancak bitmiş görünüşlü her fiilin "aniden vuku bulma" özelliğinin olmadığı düşünüldüğünde bu semantik işareti belirleyen temel etkenin "anilik" anlamı taşıyan zarfların varlığı olduğunu belirtmek gerekir.

Bondarko (1971: 15), belirtilen söz konusu semantik işareti niteleyen bu zarfların bitmemiş fiillerle kullanımının yalnızca bağlamın ifade ettiği anlama ait bazı özel şartlar dahilinde, özellikle de hikaye şimdiki zaman biçiminde mümkün olabileceğini ifade eder. Öyle ki Rusçada bitmemiş görünüşün şimdiki zaman biçimi geçmiş zamanın ifadesinde de kullanılabilir ve bu zamansal biçim "hikaye şimdiki zaman" (настоящее историческое) olarak adlandırılır. Önemli bir stilistik yöntem olan "hikaye şimdiki zaman"ın kullanımı geçmiş olayların anlatımına renkli ve canlı bir hava katmaktadır (Galkina, Gorşkova ve Şanski, 1958: 356). Dolayısıyla eylemin aniden ortaya çııışını gösteren bu semantik işaret, söz dizimsel ve leksik koşullar dahilinde nadir olarak bitmemiş fiilleri de yansıtabilir.

\section{Örnekler}

- Слушали мы, слушали, и вдруг всех нас осенила одна и та же мысль. (A. Çеhov, Kabuğuna Sinmiş Adam): Bitmiş görünüşlü fiil (CB) - ani meydana geliş - temel gösteren: вдруг (aniden).

(Dinliyor, dinliyorduk, aniden hepimizin de aklina ayn fikir geldi.)

- Вдруг Весовщиков громко_засмеялся, широко открыв рот. (M. Gorki, Ana): Bitmiş görünüşlü fiil (CB) - ani meydana geliş - temel gösteren: вдруг (aniden).

(Vesovşikov ă̆ızını genişçe açarak aniden yüksek sesle gülmeye başladı.)

- Он только внезапно проснулся на рассвете и вдруг сел, побледнев. (İ. Bunin, Neşeli Ev): Bitmiş görünüşlü fiil (CB) - ani meydana geliş - temel gösterenler: внезапно (birden), вдруг (aniden).

( $O$, birden şafak sökerken uyandı ve benzi atmış bir şekilde aniden doğruldu.)

\footnotetext{
Adres $\mid$ Address

İstanbul Medeniyet Üniversitesi, Eğitim Bilimleri Fakültesi, Türkçe

ve Sosyal Bilimler Eğitimi Bölümü, Türkce Eğitimi ABD Cevizli Turkish and Social Scinces Education, Turkish Language Teaching

Kampüsü, Kartal-İstanbul/TÜRKIYE $\quad$ Education, Cevizli Campus, Kartal-İstanbul /TURKEY e-posta: editor@rumelide.com $\mid$ e-mail: editor@rumelide.com
} 
- И вдруг начинает кричать Стамбулу, лунной ночи, что он один и погибает. (İ. Bunin, Çığlık): Bitmemiş görünüşlü fiil (HCB) - ani meydana geliş - temel gösteren: вдруг (aniden) - hikaye şimdiki zaman anlatımı.

(Ve aniden İstanbul'a , mehtaplı geceye yalnı öldüğünü haykırmaya başlar.)

\section{Ardışıklık}

Birbiri ardına gerçekleşen iki ya da daha fazla eylemi yansıtan ve "eylemlerin ardışıklığı" olarak adlandırılan semantik işaret, genellikle bitmiş görünüşlü fiillere özgü bir özellik olarak karşımıza çıkar.

Eylemlerin art arda gelişini gerekli kılan bazı durumlar vardır. Bunlar, birbirleri ile karşılıklı ilişki içinde olan eylemlerde birinin diğerinin gerçekleşmesine etki etmesi, bir eylemin son aşaması ile diğer eylemin ilk aşamasının çakışması ile meydana gelen bütünsel eylemlerin ardışıklığı, bir eylemin diğerinden önce gerçekleşmesinin önceliğini vurgulayan gösterenlerin yer aldığı ardışıklık, biri bütünsel diğeri nihai olan eylemlerin sıralanması (Şelyakin, 1983: 102-103) gibi durumlardır. Söz konusu semantik işaret söz dizimsel ve leksik bir takım koşullara bağlı şekilde nadir olarak bitmemiş fiillere de özgü olabilir. Bu durum özellikle hikaye şimdiki zaman ve tekrarlayan eylemlerin geçmiş zaman biçimi için geçerlidir.

\section{Örnekler}

- Я кончил свой завтрак, закрыл листьями мед в котелке, завязал котомку и не спеша двинулся вослед ушедшим, постукивая кизиловой палкой о твердый грунт тропы. (M. Gorki, İnsanın Doğuşu): Bitmiş görünüşlü fiil (CB) - ardışıklık

(Kahvaltımı bitirdim, tencerenin içindeki bah yapraklarla örttüm, strt çantamı bağladım ve patikanın sert toprak zeminine doğru kızılcık sopasıyla vurarak acele etmeden gidenlerin arkasindan hareket ettim.)

- Червяков кашлянул, подался туловищем вперед и зашептал генералу на ухо. (А. Çehov, Memurun Ölümü): Bitmiş görünüşlü fiil (CB) - ardışıklık

(Çeryakov öksürdü, öne doğru eğildi ve generalin kulağına fisıldadı.)

- Егорушка снял пальто, поцеловал руку дяде и о. Христофору и сел за стол. (A. Çеhov, Bozkrr): Bitmiş görünüşlü fiil (CB) - ardışıklık

(Yegoruşka paltosunu çıkard, amcasının ve o. Hristofor'un elini öptü, masaya oturdu.)

- Утром он молча пил чай и_уходил на работу, в полденьдялялся обедать, за столом перекидывались незначительными словами, и снова он исчезал вплоть до вечера. (М. Gorki, Ana): Bitmemiş görünüşlü fiil (HCB) - geçmiş zamanda tekrarlayan eylem - ardışıklık (Sabahleyin konuşmadan çayın içiyor ve işe gidiyordu, öğlen yemek yemek için geliyor, bir iki önemsiz laf ediyor ve tekrardan akşama kadar ortadan kayboluyordu.)

\section{Eşzamanlılık}

İki ya da daha fazla eylemin aynı zaman diliminde dolayısıyla eş zamanlı olarak gerçekleştiğini vurgulayan semantik işarete "eşzamanlılık" denir. "Eşzamanlılık" olgusu çoğunlukla eylemin tamamlanmamışlı̆̆ını gösteren bitmemiş görünüşlü fiillere özgüdür. Bir eylem gerçekleşirken aynı

\footnotetext{
Adres | Address

İstanbul Medeniyet Üniversitesi, Eğitim Bilimleri Fakültesi, Türkçe İstanbul Medeniyet University, Faculty of Education Sciences, ve Sosyal Bilimler Eğitimi Bölümü, Türkçe Eğitimi ABD Cevizli $\quad$ Turkish and Social Scinces Education, Turkish Language Teaching Kampüsü, Kartal-İstanbul/TÜRKIYE $\quad$ Education, Cevizli Campus, Kartal-İstanbul /TURKEY e-posta: editor@rumelide.com 1 e-mail: editor@rumelide.com
} 
zaman diliminde bir başka eylem ya da eylemlerin gerçekleşiyor olması sıkça karşlaşılan bir durumdur.

Eşzamanlılı̆̆ın anlamı ile ilgili söylemlerin çoğunda ortaya çıkan en genel kural, gerçekleşen eylemlerin bileşimine, her zaman süreçsellik ve uzunluğu öngören ani olmayan özellikteki bir ya da birden fazla eylemin girdiği kuralıdır (Polyanski, 1987: 247). Bu durumun bitmemiş görünüşteki eylemin süreçsellik özelliğinden kaynaklandığı söylenebilir. Çoğunlukla bitmiş görünüşlü fiillere özgü olan, ancak bazı söz dizimsel ve leksik koşullar dahilinde zit görünüşlü fiilleri de yansitabilen "ardışıklık" semantik işaretinde olduğu gibi, "eşzamanlılık" işaretinin de benzer koşullar çerçevesinde nadir olarak bitmiş görünüşlü fiilleri ifade ettiği söylenebilir.

\section{Örnekler}

- Они гуляли и говорили о том, как странно освещено море; вода была сиреневого цвета, такого мягкого и теплого, и по ней от луны шла золотая полоса. (A. Çehov, Küçük Köpekli Kadın): Bitmemiş görünüşlü fiil (HCB) - eşzamanlılık

(Onlar geziniyor ve denizin ne kadar tuhaf bir şekilde aydınlandiğını konuşuyorlardı; su yumuşak ve tatlı bir leylak rengindeydi, üzerinde ise aydan yansıyan altın renginde bir çizgi vardı.)

- Она слушала и печально качала головой, чувствуя что-то новое, неведомое ей, скорбное и радостное, - оно мягко ласкало ее наболевшее сердце. (M. Gorki, Ana): Bitmemiş görünüşlü fiil (HCB) - eşzamanlılık

(O dinliyor ve bilmediği, yeni, kederli ve neşeli bir şey hissederek üzgün bir şekilde başını salliyordu, bu şey onun sizlayan kalbini nazikçe okşuyordu.)

- Петя и Андрюша, худенъкие, бледные мальчики с большими глазами, брали графинчик и говорили растерянно: - Не надо, папочка... Довольно, папочка... (A. Çehov, Anna Nişanı): Bitmemiş görünüşlü fiil (HCB) - eşzamanlılık

(Petya ve Andruşa, iri gözlü, zayıf, solgun benizli çocuklar sürahiyi kaldırıyor, şaşkın şaşkın "tamam artık babacığım... Bu kadarı yeter..." diyorlardı.)

\section{Sonuç}

Rusçada morfoloji alanındaki çalışmalara bakıldığında, sözcük türlerinden "fiil” kategorisinin, "görünüş" (вид), "zaman” (время), "kip”(наклонение), "çаtı”(залог) gibi alt kategorileri ve kendine has özellikleriyle önemli bir yere sahip olduğu görülür. Eylemin akışındaki farklılıkları ifade eden "görünüş kategorisi" fiilin "bitmişlik-bitmemişlik" olgularına göre kullanımı açısından diğer kategorilerin de temelini oluşturur. Bu bağlamda söz konusu kategorinin ifade ettiği durumların çok iyi bir şekilde kavranması gerekir.

Rusçada bitmiş ve bitmemiş görünüşlü fiilleri birbirinden ayırt etmenin bazı yolları vardır. Bir fiilin sahip olduğu biçimsel özellikleri, o fiili mastar halde iken tanımaya yardımcı olabilir. Fiilin sahip olduğu biçimsel özellikler ait oldukları görünüş türünün bir çeşit biçimsel göstereni olarak değerlendirilir. Bu gösterenler kelime yapıcı ön ek ve son ekler, fiil kökünde ve vurgu yerinde değişiklik ya da fiilin tamamen değişimi olarak ortaya çıkabilir. Görünüş türlerinin zamansal paradigmaları da farklılık gösterir. Bitmiş görünüşlü fiiller geçmiş ve gelecek zamanı yansıtırken, bitmemiş görünüşlü fiiller geçmiş, gelecek ve şimdiki zamanı ifade eder. Rusçada söz konusu kategoriye özgü biçimsel özelliklere kıyasla anlamsal özellikler daha çok ön plana çıkar. Kategoriyle ilgili çalışmalar

\footnotetext{
Adres $\mid$ Address

İstanbul Medeniyet Üniversitesi, Eğitim Bilimleri Fakültesi, Türkçe İstanbul Medeniyet University, Faculty of Education Sciences, ve Sosyal Bilimler Eğitimi Bölümü, Türkce Eğitimi ABD Cevizli Turkish and Social Scinces Education, Turkish Language Teaching Kampüsü, Kartal-İstanbul/TÜRKIYE $\quad$ Education, Cevizli Campus, Kartal-İstanbul /TURKEY e-posta: editor@rumelide.com 1 e-mail: editor@rumelide.com
} 
incelendiğinde eylemin başlangıç, sonuç, yoğunluk, devamlılık gibi biçimlerini yansıtan "eylemin gerçekleşme biçimleri”, görünüş türlerine özgü bazı "özel anlamlar” ve "bütünlük”, "süreçsellik”, "uzunluk" gibi genel semantik işaretlerin ele alındığı görülür. Bu bakımdan görünüş kavramı altında şekillenen bitmiş-bitmemiş görünüşlü fiillerin anlamsal özellikleri, iyi bir algı ve doğru kullanım açısından çok daha önemli bir görüntü çizer.

Bu çalışmada Rusçadaki görünüş kategorisinin iki türü olan bitmiş ve bitmemiş görünüşlü fiillere özgü semantik işaretler incelenmiştir. İncelemede Rus dilbilimci A. V. Bondarko'nun sınıflandırması temel olarak ele alınmış ve her bir semantik işaret örnekler dahilinde detaylandırılmıştır. Buna göre görünüş kategorisinin temel işaretleri "bütünlük", "süreçsellik", "sınırlandırılmışlık / sınırlandırılmamışlık", "uzunluk", "ani meydana geliş”, "ardışıkllk” ve "eşzamanlılık”tır. Bu işaretlerden "bütünlük”, "ani meydana geliş" ve "ardışıklık” çoğunlukla bitmiş görünüşlü fiillere özgü işaretler olarak değerlendirilirken, "süreçsellik", "sınırlandırılmışlık / sınırlandırılmamışlık", "uzunluk" ve "eşzamanlılık" bitmemiş görünüşlü fiilleri yansıtan işaretler olarak ortaya çıar.Ancak bazı leksik ve söz dizimsel koşulların sağlanması durumunda "süreçsellik" dışındaki diğer semantik işaretlerin nadir de olsa zıt görünüş türünü yansitabileceği durumlar da söz konusudur.

Fiilin temel kategorilerinden biri olarak değerlendirilen "görünüş kategorisi”nin Rusçanın morfolojisinde "fiil" başlığı altında temel bir konuma sahip olduğu söylenebilir. Rusçada fiillerin doğru kullanımı açısından söz konusu kategorinin ifade ettiği özellikleri incelemek gerekir. Rusçada bitmiş ve bitmemiş görünüşlü fiillerin kullanım kurallarının yer aldığı pek çok pratik çalışmanın varlı̆̆ından söz edilebilir. Ancak kendi içinde karmaşık bir yapıya sahip olan "görünüş" olgusunun özünü kavramadan bu çalışmalardan tam anlamıyla istifade edilebileceği düşüncesi doğru bir yaklaşım olarak kabul edilemez. Bu bağlamda "görünüş" kavramını izah eden bitmiş ve bitmemiş görünüşlü fiillerin oluşum biçimleri, eylemin yansıttığı biçimler ve eylemin sınırlarını belirleyen semantik özellikleri iyi kavramak gerekir.

\section{Kaynakça}

Bak H. (2017). Faktorı vliyaniya na smıslovie otnoşeniya v predlojeniyah russkogo yazıka. Shevchenko Institute of Literature of the National Academy of Sciences of Ukraine Khmelnytskyi Humanitarian-Pedagogical Academ, C.20, S 2. 212-220.

Beloşapkova A. V. (1989). Sovremennıy russkiy yazık. Moskva: Vısşaya şkola.

Bondarko A. V. (1971). Vid i vremya russkogo glagola (znaçenie i upotreblenie). Moskva: Prosveşenie.

Bondarko A. V. (1987), Vremennaya lokalizovannost. A. V. Bondarko (Ed.), Teoriya funktsionalnoy grammatiki. Vvedenie. Aspektualnost. Vremennaya lokalizovannost. Taksis içinde (s. 210-230) Leningrad: Nauka.

Galkina-Fedoruk Y. M., Gorşkova K. V., Şanski N. M. (1958). Sovremennıy russkiy yazık. Moskva: Gosudarstvennoe uçebno-pedagogiçeskoe izdatelstvo ministerstva prosveşeniya RSFSR.

Gureviç V. V. (2008). Glagolnıy vid v russkom yazıke: znaçenie i upotreblenie. Moskva: Flinta-Nauka.

Kasatkin L. L., Klobukov Y. V.: Lekant P. A. (2004). Sovremennıy russkiy yazık. Slovar-spravoçnik. Moskva: Prosveshenie.

Korkmaz Z. (2007). Türkiye Türkçesi Grameri (Şekil Bilgisi). Ankara: Türk Dil Kurumu Yayınları.

Lopatin V. V., Lopatina L. Y. (2001). Russkiy tolkoviy slovar. İstanbul: Multilingual Yabancı Dil Yayınları.

Maslov YU, S. (2006). Vvedenie v yazıkoznanie. Moskva: Akademiya.

Ojegov, Şvedova. (2008). Tolkoviy slovar russkogo yazıka. Moskva: OOO “ITI Tehnologii”.

\footnotetext{
Adres | Address

İstanbul Medeniyet Üniversitesi, Eğitim Bilimleri Fakültesi, Türkçe İstanbul Medeniyet University, Faculty of Education Sciences, ve Sosyal Bilimler Eğitimi Bölümü, Türkce Eğitimi ABD Cevizli Turkish and Social Scinces Education, Turkish Language Teaching Kampüsü, Kartal-İstanbul/TÜRKIYE $\quad$ Education, Cevizli Campus, Kartal-İstanbul /TURKEY e-posta: editor@rumelide.com 1 e-mail: editor@rumelide.com
} 
Polukhina YA. P. ve Tumakova Y. V. (2014). Russkiy yazık (s praktikumom po russkomu pravopisaniyu i kalligrafii). Tyumen: Tyumenskiy gosudarstvenniy universitet.

Polyanski S. M. (1987). Odnovremennost/raznovremennost i drugie tipı taksisnıh otnoșenii. Otnoşeniya odnovremennosti. A. V. Bondarko (Ed.), Teoriya funktsionalnoy grammatiki. Vvedenie. Aspektualnost. Vremennaya lokalizovannost. Taksis içinde (s. 243-253) Leningrad: Nauka.

Rozental D. E., Golub İ. B. ve Telenkova M. A. (2010). Sovremennıy russkiy yazık. Moskva: Airis-press. Sebzecioğlu T. (2016). Dilbilim Kavramlarıyla Türkçe Dilbilgisi. İstanbul: Kesit.

Şelyakin M. A. (1983). Kategoriya vida i sposobı deystviya russkogo glagola. Tallin: Valgus.

Zaliznyak A. A. ve Şmelev A. D. (2000). Vvedenie v russkuyu aspektologiyu. Moskva: Yazıki russkoy kulturı. 